\title{
MANAJEMEN PEMBELAJARAN PROGRAM AKSELERASI DALAM PERSPEKTIF PENDIDIKAN ISLAM DI SMP NEGERI 2 KOTA SOLOK
}

\author{
Gusfiti \\ Guru Agama Islam SD Negeri 10 Nan Ba limo \\ Kecamatan Tanjung Harapan Kota Solok, HP. 085274881778 \\ email: gusfitrisuharta @ymail.com \\ $+20$
}

\begin{abstract}
Learning Management Acceleration Program in the Perspective of Islamic Education in Junior High School 2 Solok. The problem in this study is that the gifted child education if not given in accordance with its characteristics, allowing for their inappropriate behavior as often out of the classroom, picking teacher in learning, like teasing and love searching for attention, easily bored, annoyed and indifferent in learning. In fact, many of them school dropouts are gifted, but because it does not obtain appropriate educational experience, they can be an underachiever. To overcome this condition, SMP Negeri 2 Solok held Acceleration Program.
\end{abstract}

This study aims to describe the learning management accelerated program, and how the view of Islamic education on an accelerated program at SMP Negeri 2 Solok .

Kata Kunci: Manajemen pembelajaran, program akselerasi

\section{PENDAHULUAN}

Manusia telah diciptakan oleh Allah SWT sebagai makhluk mulia dan setiap manusia diciptakan dengan kondisi yang berbeda-beda. Sebagian dari manusia diciptakan dengan keunggulan intelektual dan mereka biasa disebut sebagai manusia cerdas. Keberadaan kelompok manusia cerdas adalah suatu potensi sumber daya manusia yang dapat membawa perbaikan di segala relung kehidupan. Namun, mereka juga akan dapat membawa kehancuran apabila menyalahgunakan kecerdasannya tersebut. Di sinilah tugas para pendidik untuk mengantisipasi segala kemungkinan negatif yang akan muncul dan untuk terus menggali dan memperhatikan keseimbangan pendidikannya. Jika anak berbakat dibatasi dan dihambat dalam perkembangannya, mereka tidak dimungkinkan untuk maju lebih cepat dan memperoleh materi pengajaran sesuai dengan kemampuannya, sering mereka menjadi bosan, jengkel, atau acuh tak acuh. Cukup banyak anak yang putus sekolah yang sebetulnya termasuk anak berbakat. Karena tidak memperoleh pengalaman pendidikan yang sesuai, anak berbakat dapat menjadi underachiever (yaitu berprestasi dibawah taraf kemampuan yang dimiliki) dalam pendidikan. 
Sesuai dengan tujuan dan fungsi pendidikan Nasional, memberi kesempatan yang sama pada hakekatnya berarti mengusahakan suatu lingkungan dimana semua anak mendapat kesempatan yang sama untuk mewujudkan potensi mereka secara optimal. Ini berarti pendidikan harus disesuaikan dengan bakat dan kemampuan anak didik. Implikasinya ialah bahwa bagi mereka yang memiliki bakatbakat yang luar biasa diperlukan pelayanan pendidikan khusus. Tanpa pendidikan khusus yang terprogram dan terarah, tidak mungkin seorang anak dengan sendirinya akan dapat mengembangkan bakat-bakat intelektualnya secara tepat dan positif sehingga akan berakibat merugikan anak. Penyelenggaraan program akselerasi sangat penting karena dengan memberikan pelayanan pendidikan yang sesuai dengan kebutuhan siswa yang memiliki potensi kecerdasan dan bakat istimewa akan memberikan kesempatan kepada siswa untuk dapat mengembangkan kecerdasan dan bakatnya dengan sebaik-baiknya, dengan demikian diharapkan nantinya dapat tumbuh menjadi manusia Indonesia yang cerdas dalam berfikir, terampil dalam bertindak dan berbudi pekerti luhur untuk menyongsong masa depan bangsa yang gemilang dalam menghadapi persaingan global. Agar sasaran peningkatan kualitas sumber daya manusia berhasil guna dan berdaya guna, diperlukan pendekatan layanan pendidikan yang mempertimbangkan bakat, minat, kemampuan dan kecerdasan peserta didik. Karena menurut George F. Kneller, education is the of self realization in which the self realized and develops all its potentialities. Pendidikan adalah proses realisasi diri dimana seorang individu merealisasikan dan mengembangkan semua potensinya (George F. Kneller, 1966: 14).

Dalam upaya mewujudkan penyelenggaraan program akselerasi di sekolah, dibutuhkan manajemen (pengelolaan) pendidikan yang efektif dan efisien. Hal ini karena manajemen diakui sebagai salah satu faktor yang sangat penting dalam suatu lembaga pendidikan, di antaranya ditentukan oleh kualitas manajemen yang dijalankan. Tujuan pendidikan akan tercapai dengan baik jika seluruh komponen belajar sekolah terkondisi, artinya segala hal yang berkaitan dengan proses pembelajaran terkondisi untuk melayani perbedaan sesuai dengan perkembangan peserta didik.

Sehubungan dengan program akselerasi, SMP Negeri 2 Kota Solok semenjak tahun 2012/2013 telah menyelenggarakan program akselerasi. Program ini dilaksanakan sebagai wujud dari upaya peningkatan mutu SMP Negeri 2 Kota Solok, sebagai respon dari permintaan kepala sekolah beserta guru-guru dan pegawai yang memunculkan ide-ide cemerlang dan inovasi pembelajaran, dan juga karena SMP Negeri 2 Kota Solok memang memenuhi syarat untuk menyelenggarakan program akselerasi, seperti akreditasi sekolah A, memiliki prestasi akademik dan non akademik, serta sarana prasarana yang mendukung.

Pembelajaran program akselerasi di SMP Negeri 2 Kota Solok ini merupakan suatu hal yang baru dilaksanakan. Untuk hal yang baru, tentu membutuhkan manajemen atau pengelolaan yang baik dari kepala sekolah sebagai pimpinan dan sebagai manager dalam 
memenej pembelajaran akselerasi. Untuk tingkat SMP di Kota Solok, SMP Negeri 2 Kota Solok adalah satu-satunya sekolah yang memperoleh izin untuk penyelenggaraan program akselerasi. Program ini dibiayai langsung oleh Dinas Pendidikan Kota Solok dengan aliran dana dari APBD Kota Solok (Kepala SMP Negeri 2 Kota Solok, 10 Mei 2014).

Dalam pelaksanaan program akselerasi tentu membutuhkan kebijakan dan kemampuan seorang manager dalam memenej program ini. Dalam proses pembelajaran akselerasi ini, akan ada pemisahan antara siswa yang memiliki kecerdasan intelektual biasa dengan siswa yang memiliki kecerdasan intelektual luar biasa. Dengan adanya pemisahan antara siswa cerdas dan siswa biasa, bagaimana menurut perspektif pendidikan Islam.

Penelitian ini mengkaji dan mendeskripsikan bagaimana manajemen pembelajaran program akselerasi yang diterapkan oleh sekolah yang penulis teliti. Maka jenis penelitian yang penulis lakukan adalah penelitian kebijakan. Penelitian ini dilakukan selama tiga bulan dimulai semenjak observasi awal yang peneliti lakukan yaitu Mei 2014 sampai Juli 2014. Tempat penelitian adalah SMP Negeri 2 Kota Solok. Data yang dikumpulkan dalam penelitian ini adalah data yang sesuai dengan fokus penelitian yaitu tentang "Manajemen Pembelajaran Program Akselerasi”.

Adapun sumber data dalam penelitian ini adalah kata-kata atau ucapan lisan dan perilaku atau sikap dari subyek (informan) yang berkaitan dengan manajemen pembelajaran program akselerasi, serta dokumen-dokumen yang berhubungan dengan manajemen pembelajaran program akselerasi. Teknik pengumpulan data yang penulis gunakana dalah purposive sampling, yaitu teknik pengambilan sumber data dengan pertimbangan tertentu.Dalam memperoleh data penelitianini, peneliti memilih informan yang dianggap paling tahu dan dapat dipercaya untuk menjadi sumber data yang akurat serta mengetahui dan memahami masalah secara mendalam, sehingga akan memudahkan peneliti menjelajahi objek atau situasi yang diteliti.

Pengumpulan data di lapangan penelitilakukan dengan beberapa cara yaitu observasi, wawancara dan analisis dokumen. Analisis data dalam penelitian ini dilakukan secara kualitatif model Miles dan Huberman, yaitu data yang diperoleh disusun secara sistematis kemudian dianalisis untuk mencapai kejelasan masalah yang dibahas, apa yang dinyatakan oleh responden secara tertulis atau lisan dan juga perilakunya yang nyata, diteliti dan dipelajari sebagai sesuatu yang utuh.

\section{PEMBAHASAN}

\section{Manajemen Pembelajaran}

Konsep manajemen jika diterjemah kandalam kegiatan pembelajaran, maka menurut Syaiful Sagala diartikan sebagai usaha dan tindakan kepala sekolah sebagai pemimpinin struksional di sekolah maupun usaha tindakan guru sebagai pemimpin pembelajaran di kelas yang dilaksanakan sedemikian rupa untuk memperoleh hasil dalam rangka mencapai tujuan program sekolah dan pembelajaran (Syaiful Sagala: 2009,140). Artinya manajemen pembelajaran 
di sekolah merupakan pengelolaan pada beberapa unit pekerja oleh personil yang diberi wewenang untuk itu, yang muaranya pada suksesnya program pembelajaran. Manajemen pembelajaran bertujuan untuk menciptakan proses belajar dengan mudah direncanakan, diorganisasikan, dilaksanakan dan dikendalikan dengan baik. Dengan proses belajar yang demikian itu diharapkan pembelajaran akan berlangsung dengan efektif dan efisien. Efektif di sini artinya dapat membelajarkan siswa sehingga dapat membentuk dan meletakkan dasar-dasar kearah perkembangan sikap, pengetahuan, keterampilan dan daya cipta yang diperlukan anak didik dalam menyesuaikan diri dengan lingkungannya.

\section{Program Akselerasi}

Program akselerasi adalah pemberian pelayanan pendidikan bagi peserta didik yang mempunyai potensi kecerdasan dan/ atau bakat istimewa untuk dapat menyelesaikan program regular dalam waktu yang lebih singkat dibanding teman-temannya yang tidak mengambil program tersebut. Artinya peserta didik kelompok ini dapat menyelesaikan pendidikan di SD/ MI dalam jangka waktu 5 tahun, di SMP/ MTs atau SMA/ MA dalam jangka waktu 2 tahun. (Direktorat Pembinaan Pendidikan Luar Biasa: 2007, 33).

Program khusus bagi anak berbakat yang disebut sebagai program akselerasi ini sesuai dengan Undang-undang Sisdiknas No. 20 Tahun 2003 pasal 5 ayat 4 yang berbunyi "Warga negara yang memiliki potensi kecerdasan dan bakat istimewa berhak memperoleh pendidikan khusus"(Depdiknas: 2003).

1280 || Jurnal al-Fikrah, Vol. II, №. 2, Juli-Desember 2014
Potensi yang dimiliki oleh manusia pada dasarnya merupakan anugerah kepada manusia yang semestinya dimanfaatkan dan dikembangkan, serta jangan disia-siakan. Peserta didik yang memiliki potensi kecerdasan dan bakat istimewa, sebagaimana anak pada umumnya, juga mempunyai kebutuhan pokok akan keberadaannya (eksistensinya). Apabila kebutuhan pokoknya tidak terpenuhi, mereka akan menderita kecemasan dan keragu-raguan. Jika potensi mereka tidak dimanfaatkan, mereka walaupun potensial akan mengalami kesulitan. (Munandar. S.C. Utami: 982, 4).

\section{Manajemen Pembelajaran Program Akselerasi Dalam Perspektif Pendidikan Islam}

Firman Allah dalam QS. Az-Zukhruf ayat 32 :

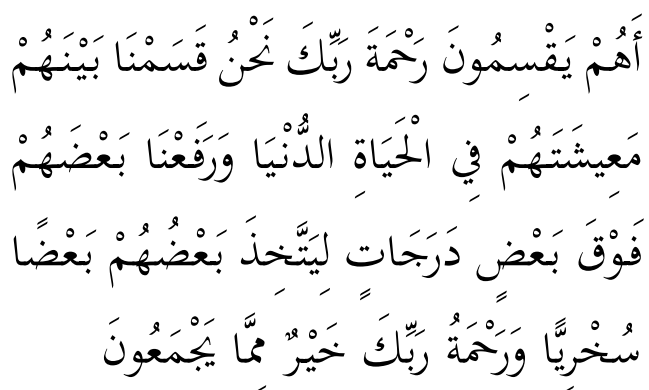

"Apakah mereka yang membagi-bagi rahmat Rabbmu Kami telah menentukan antara mereka penghidupan mereka dalam kehidupan dunia, dan Kami telah meninggikan sebahagian mereka atas sebahagian yang lain beberapa derajat, agar sebahagian mereka dapat mempergunakan sebahagian yang lain. Dan rahmat Rabbmu lebih baik dari apa yang merekakumpulkan. (QS. 43:3)

Quraish Shihab dalam Tafsir Al-Misbah menjelaskan surat Az-Zukhruf ayat 32 tersebut bahwa Allah telah membagi-bagi sarana 
penghidupan manusia di kehidupan dunia, karena mereka tidak dapat melakukannya sendiri dan Allah telah meninggikan sebagian dari mereka dalam harta benda, ilmu, kekuatan dan lain-lain atas sebagian yang lain peninggian beberapa derajat, agar sebagian mereka itu dapat mempergunakan sebagian yang lain sehingga mereka dapat saling tolong menolong dalam memenuhi kebutuhan hidupnya. Masing-masing mereka saling membutuhkan dalam mencari dan mengatur kehidupannya (Quraish Shihab: 2002, h. 561)

Hubungannya dengan program akselerasi adalah bahwa Allah SWT telah menciptakan manusia dengan berbagai macam perbedaan. Dalam hal kecerdasan, Allah swt telah memberikan beberapa kelebihan bagi sebagian orang, dalam hal ini adalah mereka yang memiliki kecerdasan istimewa ataupun bakat istimewa. Untuk mengembangkan potensi istimewa itu maka diperlukan pendidikan yang bermutu agar bisa bermanfaat bagi dirinya maupun orang lain secara maksimal.

Setiap individu berhak mendapat perlakuan atau kreativitas yang berbeda dalam pembelajaran agar potensi yang dimilikinya berkembang secara optimal, sehingga menjadi seorang yang berpredikat Ulul al-Babatau cendikiawan muslim yang dapat melatih daya intelek, daya pikir dan daya nalarnya, untuk memikirkan ayat-ayat Allah SWT baik yang terdapat dalam wahyu maupun dalam alam semesta, dan ini merupakan konsekuensi dari amanah yang diberikan oleh Allah SWT.

\section{Profil SMP Negeri 2 Kota Solok}

SMP Negeri 2 Kota Solokberada di Jl. Cindurmato No. 279 Kelurahan Tanjung
Paku, KecamatanTanjungHarapan Kota Solok. Daerah ini pada dasarnya adalah daerah pertanian yang berkembang menjadi daerah pemukiman penduduk. Dengan adanya perkembangan wilayah secara tidak langsung jumlah penduduk juga akan bertambah, tentu sangat berpengaruh kepada lingkungan SMP Negeri 2 Kota Solok, terutama pada masalah sosial, ekonomi dan budaya masyarakat. Saat ini mata pencarian penduduk adalah PNS, pedagang, wiraswasta, petani dan buruh.

Menciptakan sumber daya manusia yang berkualitas yang bersandarkan nilai-nilai budaya, sosial agama, ilmu pengetahuan dan teknologi adalah tugas berat bagi SMP Negeri 2 Kota Solok. Untuk menjawab tantangan ini dilakukan berbagai upaya secara maksimal sehingga terwujud peningkatan kualitas sumber daya manusia dan kompetensi pengelola pendidikan (Kepala Sekolah, pendidik, dan tenaga kependidikan), peningkatan sarana dan prasarana yang lebih memadai, dan peningkatan manajemen pendidikan.

SMP Negeri 2 Kota Solok berdiri sejak tahun 1952 berdasarkan pemenuhan layanan pendidikan putera-puteri yang berada disekitarnya dan telah banyak mengukir prestasi yang gemilang.Prestasiprestasi tersebut diperoleh melalui kegiatan intrakurikuler meliputi kegiatan olimpiade dan lomba mata pelajaran lainnya dan kegiatan ekstrakurikuler yang meliputi kegiatan olahraga, karya ilmiah, puisi, pidato, seni keterampilan, pramuka dan kegiatan keagamaan.

Sebelum adanya kebijakan program akselerasi, SMP Negeri 2 Kota Solok belum 
pernah mendapat peringkat I nilai UN di Kota Solok. Rata-rata baru mencapai peringkat 2 untuk tingkat SMP.Setelah adanya kebijakan program akselerasi SMP Negeri 2 Kota Solok mampu meraih peringkat I nilai UN untuk tingkat SMP di Kota Solok.

Tahun demi tahun seiring berjalannya perkembangan pendidikan di Kota Solok,SMP Negeri 2 Kota Soloksemakin dikenal dan telah banyak menamatkan siswanya untuk diterima di sekolah lanjutan tingkat atas dengan prestasi yang diukir dengan menamatkan siswa baik yang berasal dari Kota Solok maupun yang berasal dari luar Kota Solok.Prestasi sekolah/ siswa tersebut selain karena potensi siswa tentunya tidak lepas dari usaha dan kerja keras tenaga pendidik yang rata-rata lulusan S1 dan ahli di bidangnya.Keberhasilan SMP Negeri 2 Kota Solok tentu didukung jugaoleh keberadaan sumber daya yang ada. Sumber daya tersebut berupa sarana dan prasarana yang memadai yang kemudian dikelola secara efektif oleh sumber daya manusia yang berkualitas.

\section{VISI, MISI SMP NEGERI 2 KOTA SOLOK}

Visi SMP Negeri 2 Kota Solok adalah "Mewujudkan Keteladanan, Kecerdasan, Keimanan, dan Prestasi dalam persaingan global," visi ini menjiwai warga sekolah SMP Negeri 2 Kota Solok untuk selalu mewujudkannya setiap saat dan berkelanjutan dalam mencapai tujuan sekolah.

Misi SMP Negeri 2 Kota Solok adalah :

1) Menciptakan generasi berakhlak mulia dengan mengamalkan nilai-nilai karakter bangsa.

130 | Jurnal al-Fikrah, Vol. II, No. 2, Juli-Desember 2014
2) Melaksanakan kegiatan keagamaan sesuai dengan tuntunan Al-Qur'an dan Hadist.

3) Mengoptimalkan pembelajaran yang aktif, kreatif, efektif, inovatif serta menyenangkan.

4) Mengoptimalkan pelaksanaan intrakurikuler dan ekstrakurikuler.

5) Mengoptimalkan sarana dan prasarana belajar serta memanfaatkan perkembangan teknologi.

\section{PENUTUP}

\section{Kesimpulan}

Berdasarkan data dan hasil analisis yang telah dipaparkan, dapat diambil kesimpulan :

a. Manajemen Pembelajaran Program Akselerasi di SMP Negeri 2 Kota Solok

1) Perencanaan Pembelajaran

Dilakukan perekrutan siswa dengan melakukan tes IQ dan Psikologi. Guru merancang perangkat pembelajaran (Prota, Promes, Silabus dan RPP) disesuaikan dengan kalender akademik yang dibuat khusus untuk program akselerasi.

2) Pengorganisasian Pembelajaran Penyediaan guru akselerasi di SMP Negeri 2 Kota Solok direkrut dari guru reguler SMP Negeri 2 Kota Solok sendiri dan dipilih oleh pihak sekolah berdasarkan kemampuan dan prestasi mengajar serta pendidikan minimal S.1. Guru dibekali dengan memberikan pelatihan dan workshop tentang pembelajaran akselerasi. 
Kemudian dibentuk pengurus khusus program akselerasi yang terdiri dari guru-guru pilihan yang berkompeten di bidangnya masing-masing. Kurikulum disusun bereskalasi, strategi dan metode active learning, serta penyediaan sarana dan prasarana yang relevan.

3) Penggerakan Pembelajaran

Dalam pembelajaran siswa diberikan modul dalam proses belajar, menggunakan metode penugasan, ceramah, diskusi, serta penggunaan sarana dan prasarana seperti internet, laboratorium, perpustakaan dan lainlain secara maksimal. Mata pelajaran yang diberikan kepada siswa program akselerasi sama dengan program reguler, cuma jumlah jam tatap muka ditambah untuk mata pelajaran tertentu seperti; Matematika, B. Inggris dan IPA karena kelas akselerasi SMP Negeri 2 Kota Solok mengunggulkan MIPA dan Bahasa Inggris.

4) Pengawasan Pembelajaran

Kepala sekolah sebagai administrator pendidikan bertanggungjawab terhadap kelancaran pelaksanaan pendidikan dan pengajaran di sekolahnya. Guru melakukan pengawasan terhadap program yang ditentukannya dalam pembelajaran, apakah sudah sesuai dengan rencana yang telah ditetapkan atau belum.

\section{b. Manajemen Pembelajaran Program Akselerasi di SMP Negeri 2 kota Solok Dalam Perspektif Pendidikan Islam}

Allah SWT telah menciptakan manusia dengan berbagai perbedaan, termasuk potensi kecerdasan. Potensi kecerdasan intelektual manusia berbeda antara manusia yang satu dengan manusia lainnya. Perbedaan potensi kecerdasan itu menunjukkan adanya perbedaan kondisi belajar setiap individu. Manajemen pembelajaran Program Akselerasi adalah salah satu program pembelajaran yang memberikan pelayanan pendidikan sesuai dengan kebutuhan peserta didik. Manajemen pembelajaran akselerasi di SMp Negeri 2 Kota Solok dengan memisahkan pembelajaran antara siswa yang mempunyai kecerdasan biasa dengan siswa cerdas luar biasa tidaklah bertentangan dengan pendidikan Islam, karena Islam sesungguhnya menghargai adanya perbedaan. Oleh sebab itu disarankan kepada sekolah:

1) Untuk tetap mengembangkan potensi anak-anak cerdas istimewa dan bakat istimewa dengan memberikan pedidikan yang bermutu seperti pembelajaran program akselerasi.

2) Melalui pembelajaran program akselerasi, sekolah hendaknyamampu menghasilkan ilmuwan dalam berbagai bidang ilmu pengetahuan baik di bidang ilmu agama maupun ilmu pengetahuan umum.

3) Dengan adanya perbedaan potensi intelektual, pembelajaran program akselerasi dituntut untuk menjadikan peserta didik menjadi seorang yang berpredikat "Ulul al-Bab" 


\section{KEPUSTAKAAN ACUAN}

Manandar, SC. Utami,Mengembangkan Bakat dan Kreativitas Anak Sekolah: Petunjuk Bagi Guru Para dan orang Tua, Jakarta: PT. Gramedia Widiasarana Indonesia, 1992

George F. Kneller, Logic And Language of education, John Willey and Sons in inc, New York, London, Sidney, 1966
Sagala,Syaiful,Konsep dan Makna Pembelajaran Untuk Membantu Memecabkan Problematika Belajar dan Mengajar, Bandung : ALFABETA, 2009

Shihab, Quraish, Tafsir Al-Misbah, Pesan, Kesan dan Keserasian Al-quran, Jakarta : Lentera Hati, 2002

Undang-Undang RI No. 20 tentang Sisdiknas, Bandung : Citra Umbara, 2003 